\title{
東北科舅研究工作中的幾點體驗
}

武 衡

编者按: 本交原作於1952年5月，內容的调別部分和標題會作了修改。

東北科學研究所 (編者按: 1952年 8 月成立的 中國科學院東北分院，即以東北科學研究所䉆基 礎改組、撗大而成。)的建立到現在已經三年牛了， 在造三年牛中，我們是從廢墟上進行了恢復與重 建工作的，同時也逐步地展開了利學技術的研究

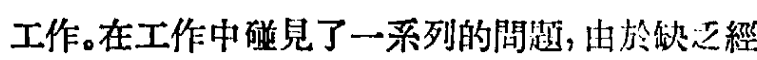
驗和認識水平的限制, 在摸索中磁了不少釬子, 但 是也得到了一些經驗。對於科學研究機關來說, 其 中一個最重要問題, 即理論與望際結合的問題。运 亳想就所體會到的一點經驗，作一個初步的介紹 興分析。

理論與實際相結合,這是馬克思、列萗主義和 毛澤東思想的基本原則。如何在科學研究中體現 它呢? 如何在科學研究中反對長期佔優攀的知識

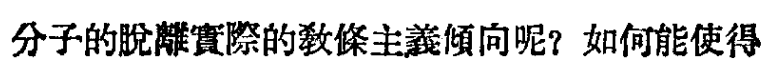
科學研究工作適應於國家建設的要求而不是單䊶 追逐“世界水平”的㽇學術而學遇的研究呢? 如何 能使科學研究工作有計劃有步嘫地進行而不是自 由散漫無政府無組織地進行呢?如何能使得科學 研究成果迅速地成篇國家建設條件或因素, 而不 是停留在“學術報告”或研究機關之內呢? 如何能 使得科學研究機夞成篇國家建設的不可少的有機 構成的一部分, 而不是可有可無的、莫測高深的 “學院”呢?這一系列的問題要求給予解答。共同網 領規定了“娺力發展自然科學，以服務於工業、農 業和國防的建設”，追規定是非常明確的，問題是 我們如何來笽現這一正確的規定。

三年多來, 主要是最近一年多來, 關於技術科 學的研究我們摸㮃到了一點經驗, 但還是很粗淺 的，也是很不完全的，這裹只提出來作笘問題討論 的開始。我想說的是: 一、研究工作計劃的整訂及
計劃執行的問題。二、中間工阔建立的間題。三、科 學研究結果的推㯺問題。四、對產業部門的合理化 建議問题。五、學㚙蘇聯的先進科學理諭與技術 閣題。

\section{一 研究工作部的的数與執行}

從1949年下牛年本所開始慗訂了1950年的研 究工作計劃, 當時是東北芼部解放之後不久, 工虽 業生㡾處於開始恢復階段, 研究所亦在恢復與重 建之中, 人員范少,設備條件简唡，對東北工農業 的情况及所需要解決的問題了解很少; 故在 1949

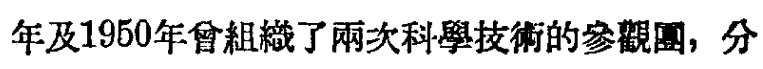
赴各故碳了解情况，搜集资料，作篇製訂研究計到 的根掉。從1950年1月開始每生年召開一次 “東北 科學研究工作報告會”, 1951年秋篇了整訂1952年 計劃, 又召開了一次“研究工作計劃會議”, 邀請東 北各应業部門的行政或技街負責同志共同研究本 所的研究工作計劃, 收效进大。此外本所及縚常派 人到各做睡進行聯繁。

1950年的計劃是很不具體的, 只有一個題目 或工作方向, 沒有詳細內容。訂計劃之前, 做必 要的茹集餈料工作及遇密的調查研究，以致在5月 間檢查計劃執行情况時, 不得不加以改變。對計劃

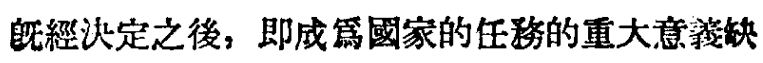
乏正確的認識，對計劃的完成與否不够重垷，乘易 修改。而領導上對於計劃的執行只是概念的重視， 蚗乏深入的檢查。在執行中往往脱耀了原訂計劃, 對如何争取完成原訂計劃茫然無知, 形成自流, 虹 文批制、指導、推動或組繶工作前進的作用。

1951年的計劃是此較進步一些了, 不僅有题 目方向, 且有了一定的步殿、淮度、人力配備及完 
成的明磪目標; 接受以往的經驗, 加上對產業部門 的聯舆了解和對主㮣力量比較正確的估計, 確 定了全年研究工作的重點, 粗織力量保證重點任 的完成。今年進行研究工作共87項, 其中基本上 完成計劃或超過計剖者 27 項, 計劃經修改後完成 者29項，兩者共56項，佔全部項目64\%。未完成計 劃者9項，佔全部項目 $10 \%$ 。此外有 22 項工作是中 涂停止了，佔全部項目 $25 \%$ (工作量则不足 $25 \%$ ), 㯰說明我們的研究工作計劃還存在着很峳重的問 碞。題目被中途停止的原因，有的是因第單純篇要 左圼上所䚴“世界水平”，瞈離了國家當前的條件和 到兵; 有的是研究方法的錯誤, 計部是正確的, 在 僬行過程中迷失了方向; 也有的是因䍃組織上的

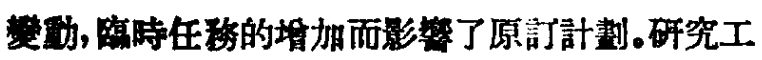

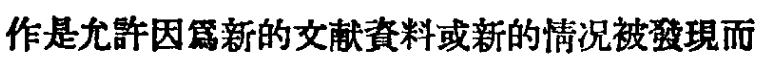
改䇣計剖或甚至中止某一部分工作的, 但是這決 不能說明上迹中止題目的全部. 縃大部分是由於 我储的思想與工作中的錯站所造成的。如果我們 能把逼一部分被錯祸使用的人力、物力隹用到最 迫勿最有的工作上去，無贸地我們的威精是會 更大的。

三年來研究工作的㣪展最雄詥地說明了, 那 些工作是人民所管要的，它就能迅速嫚展壯大並 且受到人民的数迎。

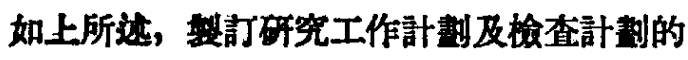
執行有那些主要的䌡驗哳?

1. 研究工作是可以做計劃的, 而且必須做計 制，有人認第研究工作本身就包含着若干未知的 因素, 不可能做計割, 运是錯部的。三年來我們每 年計劃都有進步, 就駁倒造種論點, 而通些淮步却 又都是在反對認研究工作不能做計劃或是不隹 做計劃的鬫等中取得的; 正是因篇研究工作有若 干未定因素，于必須做出計劃求得解決這些問题; 而杢要的是因第我們國家的經㴋建設是有計劃 的，研究工作既然是配合着國家建設冰進行的，那 就必須也有它自己的計剂指成篮個國家建 設、国民經注建設計劃的一部分。根㹉慗訂與執行

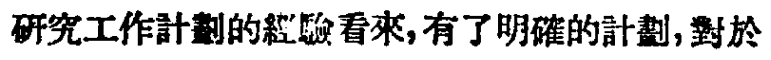
研究工作就有推動作用，對研究人員有鼓等作用， 提高他們對工作的责任感及第祖國建設服務的熱 情。而且在以後有的題目因的复時增加, 未做詳細計 劃, 反而舆得工作無法下乎。另一方面, 有了計劃,
對人力的租樴、經資、設備、儀器和䣋品的製備等 也便於進行。

2. 製訂計劃之前應有允分的準備工作: 研究 工作計劃的彆訂, 準備工作是十分重要的, 其內容 大約有以下幾項:（1)了解當前國家建設的需要， 做必要的寥䆏、訪問、調查、㸴究; (2)充分掌握资 源情况; (3) 了解工農業的技街水本及其提高的 遠景; (4)本所人力,物力的條件; (5)葛集有關 的資料文献; (6)考虑其經漂價值或學街價值。把

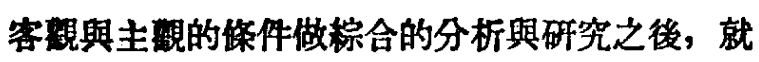
可以確定題目, 然後再指定專人負责搜集材料, 做 出計劃, 規定研究的目標、步噁。方法、進度、人力

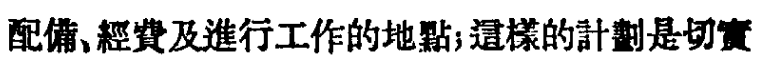
可行的, 避免了盲目性。任何一倜研究題目都隹有 準備工作及整訂計劃的兩個階段，而且要明確，淛 偖工作就是研究工作的一部分。

3. 研究工作計劃是從上到下和從下到上相 結合的: 過去本所的研究工作計劃大體上是先由 研究空提出來, 然後再交所䅂會議討論及上极偤 正興批准的。遭種方法在過去是對的，因学當時工

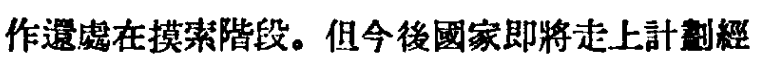

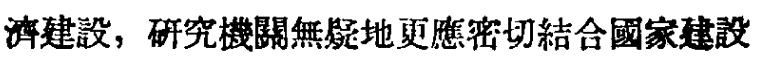
計劃，那繁毠研究室提出題目旿然是不够的了, 單靠産業部門或閔碳技術部門提出問題也是不侈 的，因第他們所了解的也只局限於目前的技衔問 闍，對行將到來的重大問題同樣是不够了解的。故 确究工作計劃就必須根搌國家建設的要求和上极 的意圖來製訂，否則就會落在國家建設之後，就會 犯錯裙。遭當然並不妨碍研究人員提出自己的意 見。同時研究計劃又必須第全能人員所甞握, 經過

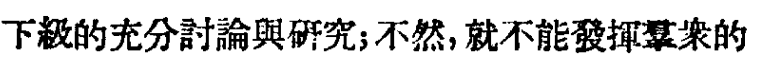
皘極性與創造性, 就要妨碍幹部的培餈。由於研究 工作佟件的限制，高級人員比下級人員必然情得 多些, 甚至有些問題下粐人員一時不易了解, 但是

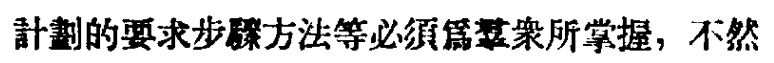
就會造成工作的損失。因此加强研究人員的辣 䠐點及集䯠主義精神是非常重要的。總之，研究工 作計劃是應由上而下地交待任路, 再由下而上地 做出計劃的具體內容, 並且要動員全解人員篇完

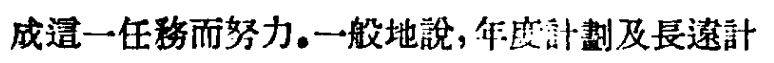
劃應由先上柽提出意胃, 再由各研究單位及研究

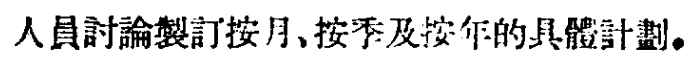


4. 研究工作計劃既經批准, 它就是國家的任

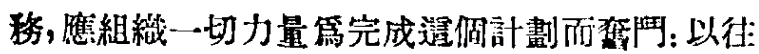
我們有些部門對計劃的重祝是不矽的, 至於能否 完成, 何㭙完成则放任自流。今後如果我們的研究

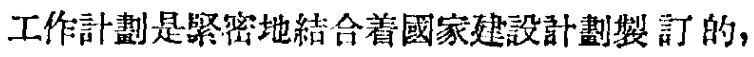
研究工作計劃不完成或是不按期完成, 就會通接 妨碍國家越設計劃的實施。篇了完成研究工作, 必

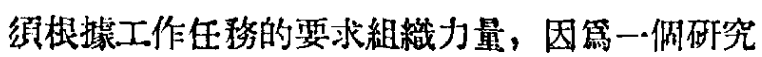
頙目往往不是一、二僻研究室所能完全揆任的。尤

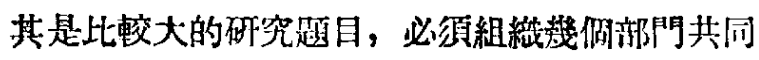
淮行，打破本位主義與畛域之見，反對佔人單搞一 套, 㯰些都是保證完成任務的關鍵。在一僻㸴究所 或一個研究室內又否有其一定時期的工作重㫮; 組織一一切力量園繞着這偑重點工作而努力。在我 们人力物力還比較缺之的條件下, 選摆重點工作, 整時放案次要的或可以延䌊的工作, 以期迅速地 解决某些國家貄設中参需解決的問题是有重要意

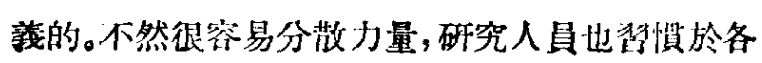
幹一套, 那就會很長洔間一事無成。篇了達到組蟣 力量, 重器地組織力量的目的, 必須不斷地向個人 主義的思想作楻等。

5. 研究工作計劃的修改: 研究工作計劃在彆 訂之前要進行週密的調查研究和潐備工作, 既訂 之後應堅持篇完成計劃而努力。但是䂰究工作本 身即帶有萑干可變因素, 隨時可能發現新的問题, 新的資科及研究人員新的創議; 如果經過谐重的 考㴽確是正碓的、先進的, 那就必須及 時 修改計 劃。必須反對㬝守成規, 固步自封, 不能瀷落後的 阻碍了先進的。要商於饬任新的萌芽來提高和改 進研究工作。始息與拖拉同核會造成提失。當然這 種修改也不應櫂䇣從事, 要有一定的泚度與程序。 計劃媓經修改之後, 同樣應異微赫行。

6. 研究工作計劃執行的檢查: 明碓的研究工 作計劃是檢查工作的根據。按照月、季、牛年、全年 的計劃進行總結, 隨時由計劃部門深入研究室進 行检查,並要經常檢查研究工作記錄。检查研究工 作記錚對於了解研究工作的進度、等㽖初粐研究

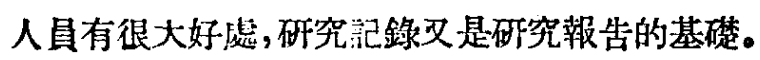
又因篇本所研究工作與坆硣聯熬較多，出差亦多，

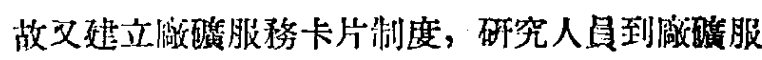

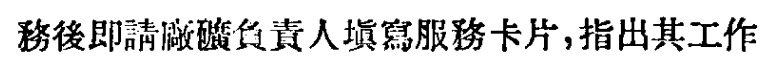
的成績與缺點, 作第今後改進的根據。
7. 用合闹的形式把碑究工作第商業部門服

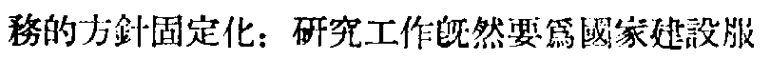

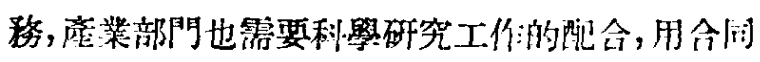

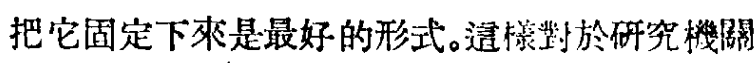
来說就有了明淮的服務對象與目標, 迨些合|闰的 內容成第計劃的一部分, 對於產業淤門桃說也有

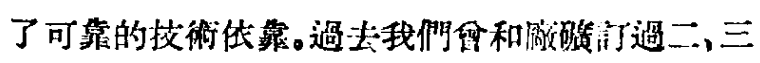
十件合同。

要把研究工作計劃作好, 文能其徽執行, 上麻

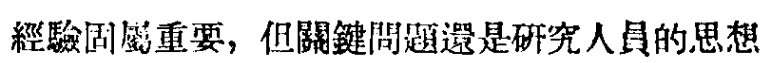
開题。在思想改造運動中悬露了我們科學研究人

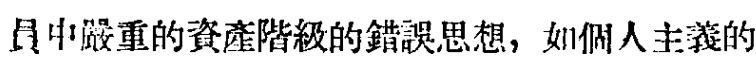

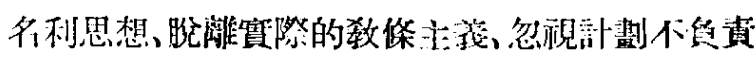

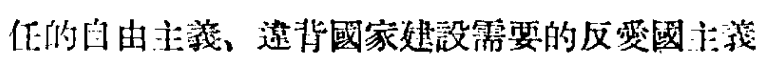

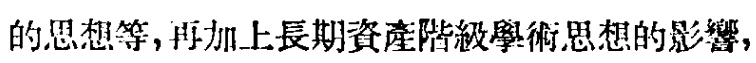

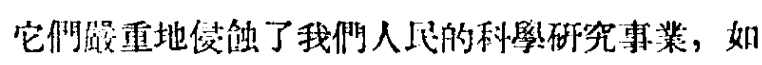
不加以徽戍的揭發與批判, 就不能完成國家所践 予我們的重大任務。毛主席㮞码我們進行思想改 造速動, 上述錯誤思想已經得到济步的批刵, 今後

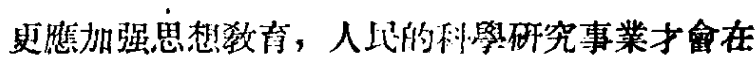
毛澤東思想指䆃下不斷前進。

\section{二 中間工廠的建設}

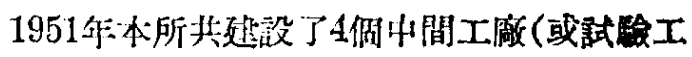
殿)，投資額約佔全所總經費 $1 / 5$ 弱，組織了很大一批人力, 是當做全年的重點工作來進行的。迹些 工阔的建設使研究工作大大提高了一步, 使科學 研究與生座中間的距離大大的縮短了或消減了。 使貫驗的工作有了工業化或贯用的可能，同時也 暴露了研究工作中的弱點。造䂱明中間工敵的建 立是科學技術與筫際結合、篇工業建設服務所必 需的。中間工榈對科學研究的作用是什燃呢?

1. 證明研究工作的結果可能工業化，貫用 化。

2. 在中間試驗中來補充或修改試驗室 的続

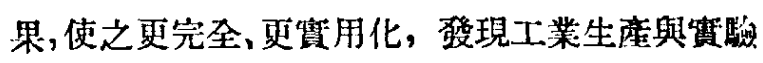
室不同的現像，找出在實驗室不能得到的保件與 數㨜。

3. 試驗機器設備性能及材料性能, 從而加以

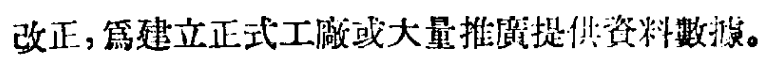

4. 培養做設計、安裴、操作控哪的技街翰部

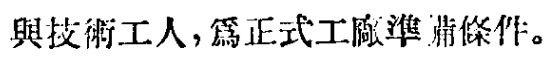


在研究所中搞中間工阔還是一種新型的工 作，要把遭润工作做好，必須首先明碓研究工作是 篇了國家工業化或惯用化，研究人員要建立第國

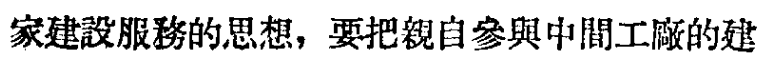
設及富驗等工作, 罍做自己研究工作任務的一部 分。其次要有集體主義的精神與工作作風，與工

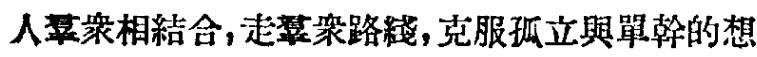
法和做法。再次要有明確的經鸡核算思想，因中間

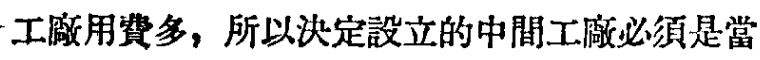
前國家建設所急需的，在試驗中亦應考虑到經泳 核算的問題。

建設中間工微中又有下列經驗敎訓是值得注 澺的:

1. 在研究工作中就㮣有建設中間工僘的思

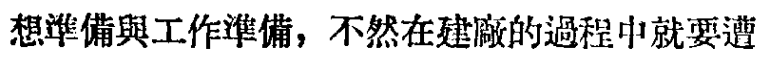
到很大的困難。例如本所有一阎工澈的建設是比

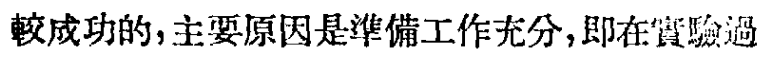
程中已考虑了工業化的必要條件與数挂, 故建做

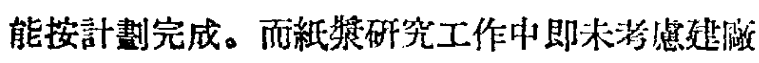
的需要, 故建坆中墢生很大的䦌题, 䓕至連設計的 基本要求都须討論，建做中走了很大琴路，米能 按期完成任務。

2. 在試驗室中即哕洘虑工恶生產條件的可

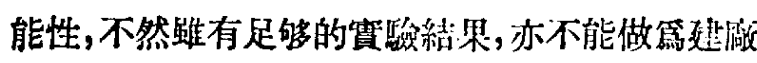
的根㨜。如硫酸解媒釩的抽出法, 用水量是 $1: 8$, 在

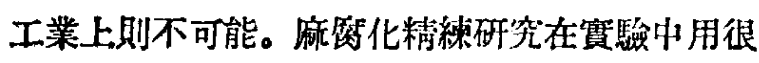
少的麻、大量的水，使用蛋白凍做菌的唔養基，而

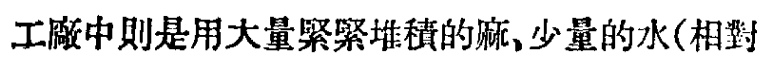
比)，且蛋白凍價值昂贵，根本不可能使用。故惯驗 室工作就應首先考虑這些工業生產的條件, 滿足 趐阔設計的需要。

3. 中間工故的建設以能完成研究工作所必 需的工業化試驗篇目的, 應集中力量於主要的試

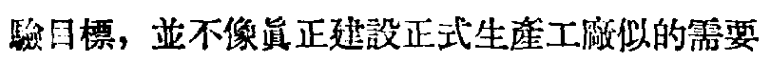
完整的一坛, 更不必要全部機械化。例如原料的運

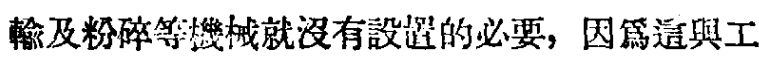
業化試驗是無關的，而在大工敵中则有荤輸帶及 粉碎機的既成没汁。又如荣些連䅼操作或流水作 業在正式工做中圆虚必需，在中間工殿也完全可 以不必。逜樣就可以節省無数人力物力, 收事坐功 倍之效。

4. 中間工䯘所採用的機器及操作方法, 䇛可
能是一般化的或潔潐化的，便於將冰建設生产工

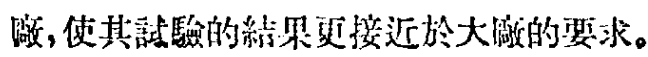

5. 中間工撽㮣採用 先進的技街 及先進的機

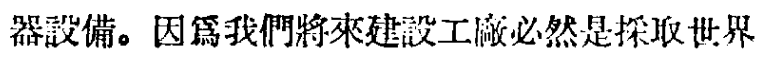

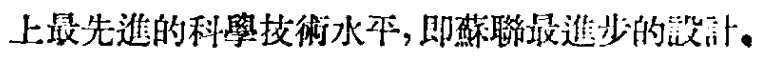
反對守鹤的、陳留的、资标主義的落後技衔與設 備。

6. 中間工阙在設計、建案與試車中都必須有

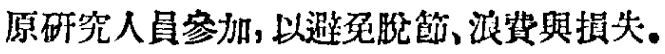

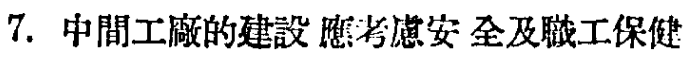
佟作，㾞產階級建設工做不考虑㯰些條件，而我們 必须重視咳倜問題。

\section{三 科學研究結果的推度}

本所於1951年已阙始蔀份地將研究工作的絬

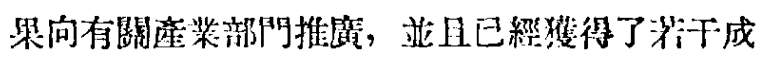

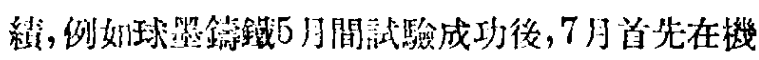

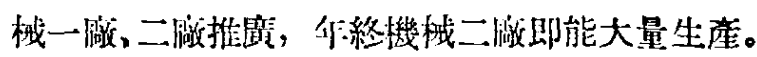

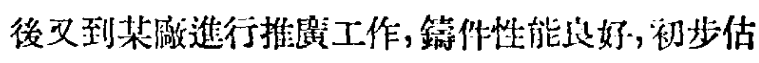

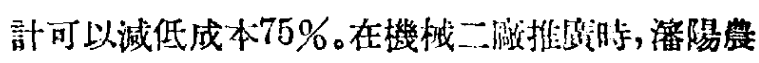

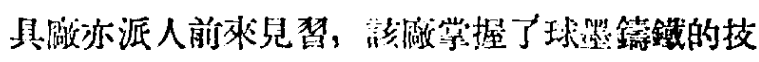

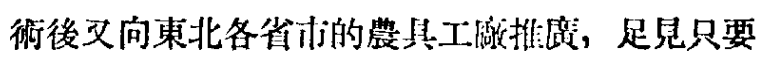

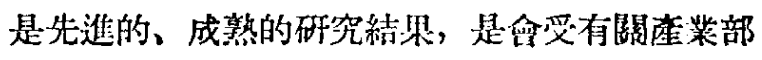
門粼迎的。其次以䬫出䗨提高汽缸海生産的研究

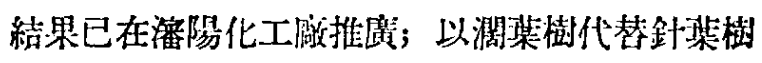

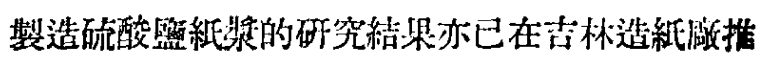
展, 且不斷派人前往工䏲了解情况與協助工作, 取 得不少成績; 大豆膠代替牛奶膠製造膠合板已在

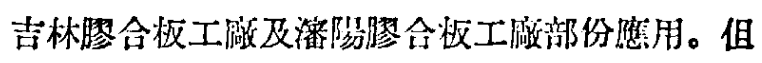

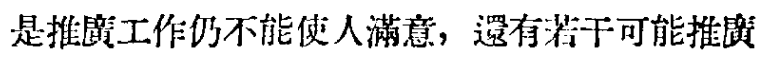
的研究絬果米立推滛, 已經做的比可能做的少得

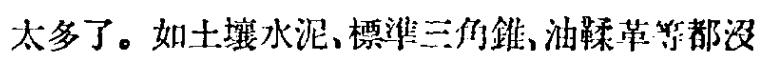

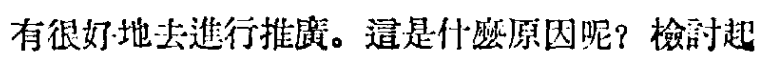
来, 大約有下列幾項:

1. 首先是由於我們的研究工作 還存在着學 院式的作風，還涩有光分初識到研究成果如果只

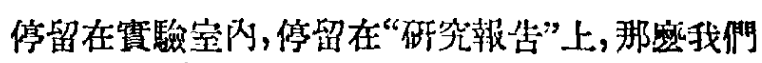

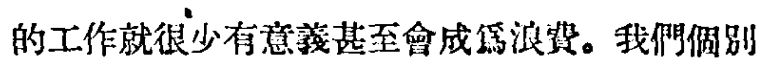
的研究人員, 政究工作完成之後, 不惜化很長的時

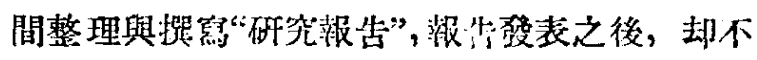
管:它在望際中所發生的結果如们。运能够垁他具

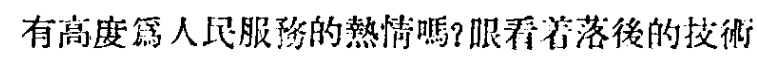


與舊的操作方法仍然被使用着，並無意以自己所 創造的、研究的新的先進技術來代替它，能喽馀 逼是科學家應有的態度嗎? 他們往往說推展是工 業部門的事情, 但是一種新的發明刢造, 如果沒有 研究機關，及原研究人員負責地、熱情地予以宣傳 推厝, 不是束之高閣, 就是走很多繁路, 拖延很長 時間,造成損尖與浪資。明確推簧研究成果是研究

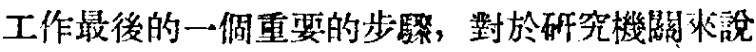
是非常重要的。

2. 其次對於推韦工作就是 研究工作的一部 份, 缺之明確的認識。試䲆室內的工作，包括中間

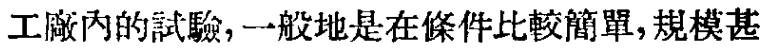
小的情况下進行的, 把試驗的結果拿到工農菜中 去，往往有許多焂件必須加以修改或補光。麻的管 化精鍊就是一偑例了，在試䮑室中以蛋白凍培食 少量的菌，做少量酒麻試駿是成功了, 但是大規模 生就不可能了, 必須重新進行試駿, 以前的“成 功”, 只能作焉以後試驗的隻備步驟。如果我們只做 前一步, 不做後一步，也可能察出一份“完整的”報 告, 但是對於實際㵐的华化精練則不能發生任何 作用。其他的研究工作大䀧上也有類似情况, 藉推. 席工作來修正與補夻研究工作不僅是研究工作所 必需, 對於㸴究人員工作能力的提高, 感性知識的 豆富，克服䁅院侙敉條主義的思想方法，同樣是最 實際的敎吉。

3. 認第推廊工作是產業部門的事情, 或者認

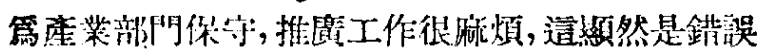

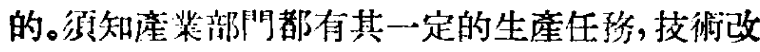
進或先進生産力法的被吸收是完成或超過生産任 務的重要條件之一。但是試行新的生產技術待往 又會暫時地影響生產，所以産業部門如果沒有充

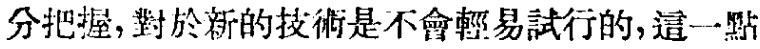
研究人員歪有无分的理解。区此研究人員到淌碳 去推麇其研究成果, 必須: 一, 具有古分的數據, 足

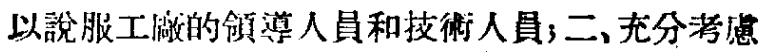

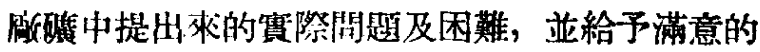
解决與答復; 三、提出明確的推廣工作目標及試行

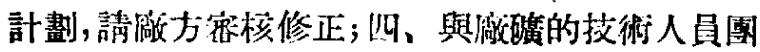
綃合作;五、推嵁工作應有始有終,有必成信心, 不

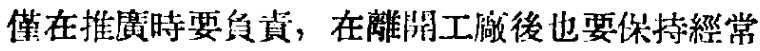

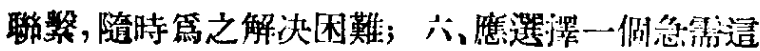
種技術的工湤作第推展對象，以健於取得其垶助
迅速滥行. 因此推盧工作的本身就不是單純的技 術工作，同時又是宣体工作和租裁工作。如以單純

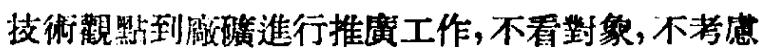

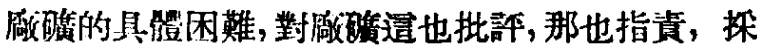
取自以篇是,好篇人们的態度，造種人去進行推度 工作是汥有不磁釘了的。反過來馀，推廣工作對於 科學邵究人員义是與實際相結合、與生產相結合、

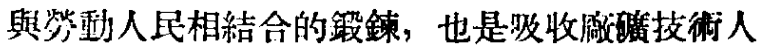

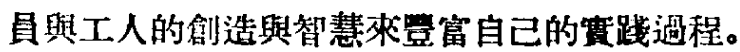
因此，我們應從思想上克服上述推廣工作的障碍， 堅持進行推廣工作，表揚與战䙲對推廣工作有成 樍的單位或個人，批評對推唇工作漠不關心，或枢 悓、推諉的現象與藉口; 要求各研究宗都做出自己 的推廣計劃, 把推廣工作的成績作䉆考植研究工 作的重要標淮之一。

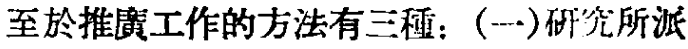

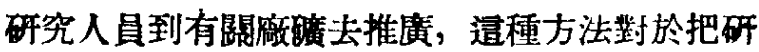

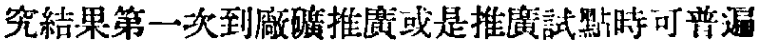
採用; (二)利用行政組織做普遍的推䧹，例如用上. 迌方法試行成功後, 即可通過組織, 通知有翡部門 採用; 也有不需要試點即可通接通知各單位探用 的, 如木材强度試驗的結果, 即山工業部通知各施 工單位採用了，因而也就推艆了; (三)用開测練班 的方法來推展，如化學分析方法改進的推墴都可 以召集有關單位的人員給予短期汌練, 即可大量 推廣。

\section{四 對産業部門的合理化建議}

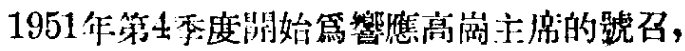
結合工業部門“找簃門”運動，發動全所科學技術 人員向各產業部門提出合理化建議。擮至作末，共

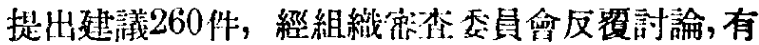
的還經過简單試驗，認篇立即叮以提出的有 84 件。

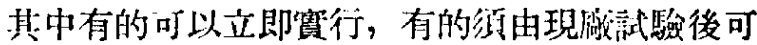
貫行，也有些不能很快筫珿，!是有必要啊有關 方泊注意或參考的。其中比洨重要的建議有: 硫酸

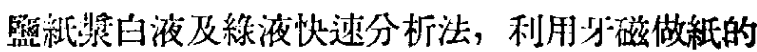
白度計，改良挴順怕油的品質，殿泛收集廢油及再

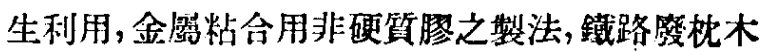
之利用,統一紅硐尺寸，利用煤灰做低强度水泥， 廣泛利用膨潤土做砂型結合㓡，廣泛探用機件之

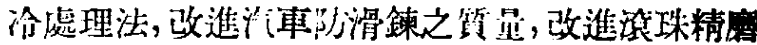




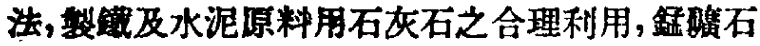

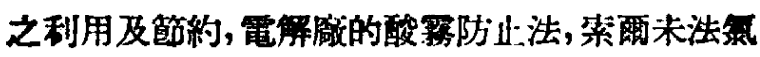
化鈁之回收利用, 粗丙酮的精彆法等等。造一運 動加强了研究人員理論與實際結合、篇生產建設 服綮、篇人民服務的觀點, 加强了與各産業部門的 聯橧。建議發出後,已接到三十多㑬座業部門的回 信, 有些很受歡迎, 有的已付諸菑行了。篇此, 我們 决定:

1. 今後配合增產節約運動繼繶開 展合理化 建議, 力求其具能可行;

2. 建議提出後, 應了解各産業部門執行情 况，總結經驗，進一步加以推廣;

3. 了解貄議埶行中的困難, 解决造些困難, 修正與充筫建議的內容, 如確屬合理可行, 應以十 分負责的態度不断地提請有關部門實行。這是科

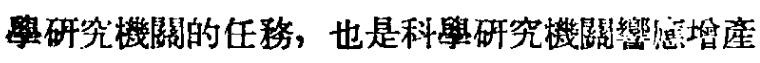
節約號召的方浩之一。

\section{五 學習苇㖒的先進理論與技術}

本所网三年來對於學晳蘇聯先淮的科學理論 與技街是做得很少的; 相反地, 目目地㮞拜美、英、 日本的科學技術還是很普避的。全所只有土木建 策研究室土壤檢驗工作組的同志在工作任務繁重 的佟件下翻譯了蘇聯 “工業及民用房屋建溆天然 基礎設計規模”及“粗空㭞土壤下沉性倎之烧籍”, 應用到賽際工作中判定士啠分類及地流少了，亚推

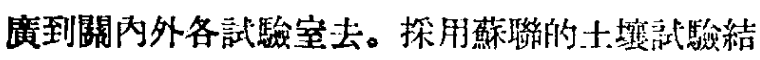
果報告表, 按表內規定項目進行試䭻, 所得結果

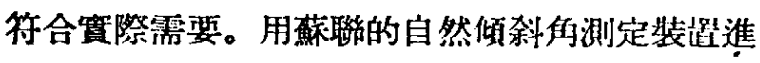
行砂士試驗, 節省了人力物力, 採用蘇聯壓密試 驗的简單方法等, 大大改善了土壤試驗工作, 滿 足現娍設計的要求。相反的, 檢驗室化了很大力 量, 挺製憸驗規程草案入大册, 大部份探取英、美、 日本的資料及做磺現行方法（以往敵碳現行方法 多斗亦是英、美、日本的)缺乏吸收蘇聯經驗, 故所 慗訂的規程是落後的, 不適用的。根據美國及日本

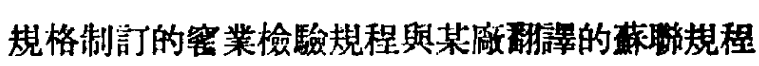
相較, 在時間方面比蘇聯的方法慢, 在隻確度方面 不如蘇聯的方法精, 是一㑬最現實的呚訓。在研究 工作中, 矽磷的研究也是一偑最朋影的例子, 害業

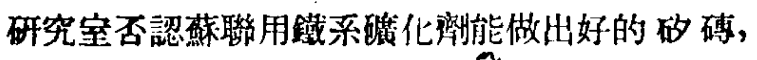
而工業生產登明了他們的落後。”怨視與拒絕接受 蘇聨先進的科學理論與技街的思想必须徹底克 服,代之以皘極的主動的學習。蘇聯的利學理諭與 技術是在馬克思列寗主義指導下弡展起來的, 因 此它最富有創造性與發展性。本所有很多蘇聯科 學圖書雜誌，但可惜很少有人能閱讀。

篇了有效地學習蘇聯先進科學, 今後應該:

1. 把研究室能够閱讀俄文的人組維起來，負 青介釈編譯伐交資料，並訂出工作計劃，按期檢 查;

2. 加强俄文學習，加强對蘇聯科學學術思想 與理諭的學少, 加强對蘇聯科學技術成就的學盾。

總結起來, 在蘇聯先進科學理諭和技衡指導 下, 在讋證登唯物主義的思想指導下, 使科學研究理 論與實際相結合，把研究工作絬果工業化、貫用 化、亚加以推廣，或是向有關部門捉的合理化建 議, 第新國服務, 篇人民服務间间時也是研究工作

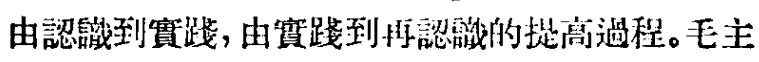
席指示我們說: “許多理論的终理性是不完全的,

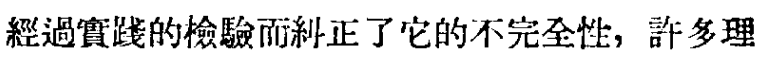

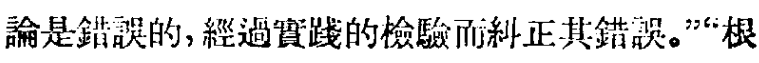
據於一一定思想、理諭、計劃、一j策以從事於變革客 觀現實的實践,一次又一次地向前, 人們對於客觀 現實的認識也就一次齐一次地哚化。”科學研究計 劃的製訂與實践、研究結果的工業化，推廣及向座 業部門捉出建議, 是研究工作第人民服務的具體 表現, 也是檢驗科學研究結果、提高科學趼究工作 質量的有效措施。

在毛澤東思想的光辉照耀下，建設人民的科 學研究事業, 使之成窎我們偉大的㱚國建設的重 要組成部份, 是我們全體科學工作者的光榮任䅂。 